\title{
Second Branchial Anomalies in Children and Literature Review
}

\author{
Çocuklarda İkinci Brankial Anomaliler ve Literatürün Gözden Geçirilmesi
}

\section{Ramazan Karabulut, Kaan Sönmez, Zafer Turkyılmaz, A.Can Başaklar}

Gazi University Faculty of Medicine Department of Pediatric Surgery, Ankara, Turkey

\section{ABSTRACT}

Second branchial arches anomalies are the most common branchial anomalies. Usually sinuses and fistulas are encountered in younger ages, while cysts are observed in adolescent or adults. Early diagnosis and treatment decreases recurrence by preventing infection, which causes adhesions in the tissue plans. Definitive treatment for these lesions are surgical excision. The aim of this study is to report our clinical experience in second brachial duct anomalies with the review of the literature.

Key Words: Second branchial anomalies, treatment, children

\section{ÖZET}

İkinci brankial ark anomalileri en sık görülen brankial ark anomalileridir. Genellikle sinus ve fistül erken yaşlarda görülürken kistler ergen ya da yetişkinlerde tespit edilir. Erken tanı ve tedavi doku planlarına yapışıklığa neden olan enfeksiyondan koruyarak rekürrensi azaltır. Bu lezyonlarda kesin tedavisi cerrahi olarak çıkarmaktır. Bu çalışmanın amacı ikinci barankial ark anomalileri ile ilgili klinik deneyimlerimizi literatür gözden geçirmesi ile beraber sunmaktır.

Anahtar Sözcükler: ikinci brankial anomaliler, tedavi, çocuklar

Geliş Tarihi: 18.11.2016

Kabul Tarihi: 07.03.2017

\section{INTRODUCTION}

Branchial anomalies occur during embryological development as a result of incomplete obliteration of the branchial cleft, and manifest themselves as cyst, sinuses or fistulas in the neck region (1). The second branchial anomalies accounts for about $90 \%$ percent of all branchial anomalies. Other branchial anomalies are considerably rare (2). The aim of this study is to report our clinical experience in second brachial duct anomalies with the review of the literature.

\section{PATIENTS and METHODS}

Between 2015 and 2016, 6 patients with second branchial anomalies have been treated at our department. The clinical records and histopathologic reports of the patients were evaluated according to age, sex, localization, radiological and histopathological findings.

\footnotetext{
Address for Correspondence / Yazışma Adresi: Ramazan Karabulut M.D. Gezegen Sokak 1/10 Gaziosmanpaşa -06670 Çankaya, Ankara, Turkey E-mail: karabulutr@yahoo.com

CTelif Hakkı 2017 Gazi Üniversitesi Tıp Fakültesi - Makale metnine http://medicaljournal.gazi.edu.tr/ web adresinden ulaşılabilir.

CCopyright 2017 by Gazi University Medical Faculty - Available on-line at web site http://medicaljournal.gazi.edu.tr/

doi:http://dx.doi.org/10.12996/gmj.2017.70
} 


\section{RESULTS}

The mean age of the 6 patients ( 4 male, 2 female) with second branchial anomalies was 3.8 years. 3 of the patients had lesion on the right side. Four of the patients with second branchial anomalies had persistent discharge from the external orifice. Two patients had a painless cervical mass on the neck. The diagnoses are easily established by means of physical examination; therefore except the patients with non-tender cervical mass, no patients are subjected to diagnostic test such as fistulography or ultrasound. None of these patients had a history of previous infection or inflammation when they were first examined. All lesions of the patients were excised by an elliptic transverse incision containing the external orifice of the tract. In order to ease the excision of the tract, inserting $3 / 0$ polypropylene suture in four patients. During the two years follow up neither recurrence nor operative complications were observed.

\section{DISCUSSION}

Six paired branchial arches, mesodermal in origin, appear between the fourth and sixth week of intrauterine development. The external and internal invaginations through the arches give rise to the development of internal endodermal pouches and external ectodermal clefts $(1,2)$.Second branchial fistulas occur when caudal grow of the second pharyngeal arch over the third and fourth arches is interrupted, leaving the remnants of the second, third, fourth clefts in contact with the surface by a narrow canal $(3,4)$. Branchial anomalies occur during embryological development as a result of incomplete obliteration of the branchial cleft, and manifest themselves as cyst, sinuses or fistulas in the neck region. The second branchial anomalies accounts for about $90 \%$ percent of all branchial anomalies which are usually located on the lateral side of the neck directly anterior to the superior one third of the sternocleidomastoid muscle (1-3). Almost $2 \%$ to $13 \%$ of the second branchial anomalies are bilateral (2-5). The course of the second branchial fistula begins from the external opening of the lesions, coursing cephalad along the lateral carotid sheath, passes between the internal and external carotid arteries and travels lateral to the glossopharyngeal, hypoglossal and superior laryngeal nerves. After moving deep to the stylohyoid muscle, it pierces the upper border of the middle pharyngeal constructor to enter the tonsillar fossa $(2,3,6)$. The second branchial cleft sinuses/cysts are classified into four types by Bailey. Type $I$ is the most superficial and lies along the anterior surface of the sternomastoid muscle, just deep to the platysma. Type II is the most common and is foundalong the anterior surface of the sternomastoid, lateral to carotidspace and posterior to submandibular gland. Type III extends medially between the bifurcation of the internal and external carotid arteries to lateral pharyngeal wall. Type IV opens into thepharynx and is lined with columnar epithelium $(7,8)$. Second branchial cleft cysts were different classified into four types by Proctor: Type I: superficial cysts lying anterior to the sternocleidomastoid muscle and beneath the cervical fascia; Type II: cysts lyingon the great vessels (the most common); Type III: lesions extending between the internal and external carotid arteries;Type IV: cysts lying adjacent to the pharyngeal wall and medial to the great vessels $(9,10)$.

Usually sinuses and fistulas are encountered in younger ages, while cysts are observed in adolescent or adults (Figure 1). Ford et al. showed in 98 cases that the majority (78\%) of second branchial anomalies are seen by the age of 5 . Most of them manifested themselves by an intermittent mucous or purulent discharge during the newborn period (4). In Agoton Bonilla's 148 cases in adults, $80.8 \%$ of the patients had cysts and the rest had fistula (11). The symptoms of our cases were discharge $(79 \%)$, cervical mass $(7 \%)$, and the presence of an external orifice (14\%)(Figure 2). Eight of our cases had had discharge since newborn period. Sometimes a skin tag or a cartilaginous remnant can be noticed around the external orifice $(1,3)$.

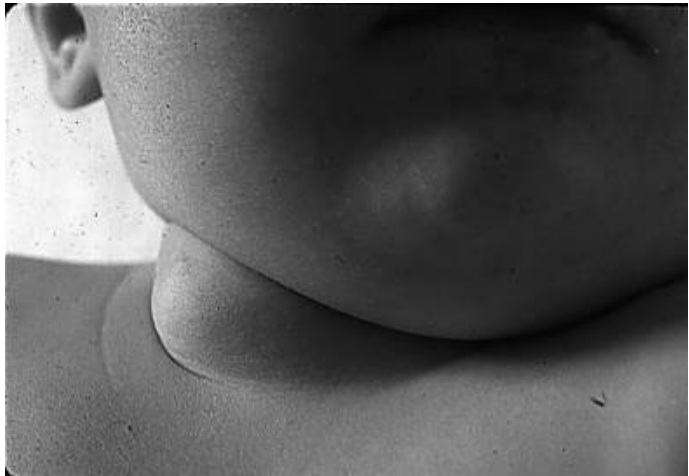

Figure 1: Second branchial cyst in an infant( Courtesy of Prof.Dr.A.Can Başaklar Gazi University Medical Faculy, Ankara,Turkey).

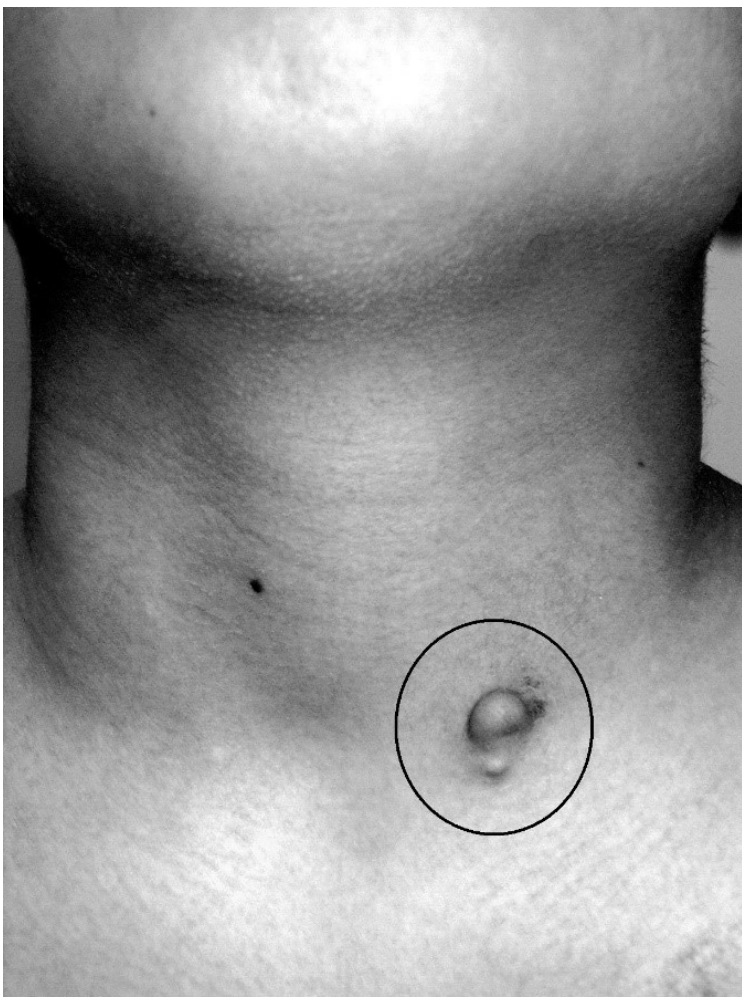

Figure 2: Second branchial fistula in a boy(Courtesy of Prof.Dr.A.Can Başaklar Gazi University Medical Faculy, Ankara,Turkey).

$\mathrm{CT}, \mathrm{MR}$, USG and fistulography are frequently used means of radiological evaluation in the diagnosis of second branchial remnants. At USG, a second branchial cleft cyst is seenas a sharply marginated, round to ovoid, centrally anechoic mass with a thin peripheral wall that displaces the surrounding soft tissues. At CT, these cysts are typically well circumscribed, homogeneously hypo attenuated masses surrounded by auniformly thin wall. The mural thickness may increase after infection. At MR, the cyst fluid varies from hypointense to slightly hyperintense relative to muscle on T1-weighted images and is usually hyperintense on T2-weighted images. But, it is adequate to reach a diagnosis by observing the external orifice and the discharge from the fistula. However, we think that it is needed to perform a CT or MR investigation in the patients with cervical mass to establish a definite diagnosis $(3,6,8,10)$. 
Some authors advocate surgical treatment of branchial anomalies at approximately 1 year of age. This view is supported by the increase of recurrences if infections precede operative treatment (12). A review of 249 deep neck infections revealed a congenital cause in 39 cases (16\%) (13). No second branchial cleft sinuses/fistulae were observed, indicating that these sinuses and fistulae are extremely rare cause of deep neck infections. Another view, the operation may be delayed to an age of approximately three years when anesthesiological risks are and possible harms are best avoided when anesthesiological risks are and possible harms are best avoided(14).

In a series of 98 cases, $50 \%$ of tracts were found to reach beyond the bifurcation of the carotis. Only two of these cases with long tract had an inner opening in the pharynx near the tonsils. The patients with a fistula reaching beyond the carotid bifurcation were operated on with a ladder incision. In spite of the comments of some authors, claiming that operation is not needed in the patient with asymptomatic second bronchial anomalies, most of these cases needed surgery for cosmetic reasons or recurrent infections. However, most authors agree that it is logical to know the course of fistula tract to reduce the rate of the recurrence. Various methods such as inserting a fogarty catheter, methylen blue injection, paraffin injection were defined to identify the course of the tract $(2,3,5,15)$. We treated our cases by inserting a $3 / 0$ polypropylene suture as a guide. By this intervention we reduce the risk of puncturing the fistula tract with a style, and also got ride of the unwanted ethylene blue effect. Furthermore, using a 3/0 polypropylene stent is much cheaper than the fogarty catheter and also easier to insert as our paitents. Early diagnosis and treatment decreases recurrence by preventing infection, which causes adhesions in the tissue plans. Operative complications include neurologic damage like glossopharyngeal or hypoglossal nerve injuries, or facial nerve injury in 3.5\%, and fistula formation, internal jugular vein trauma, infection, seroma, hematoma, and scar formation in $3.3 \%$ (11). The recurrence rate is $25 \%$ if the patient is operated after the first infectious attack (16). The overall recurrence rate after surgery is $3 \%$ to $4.9 \%$ $(4,8,11)$

In case of second branchial cleft anomalies, it is important to avoid injuryto the spinal accessory, hypoglossal, or vagus nerves(17). Chen et al. reported that endoscope-assisted resection of second branchial cleft cysts in the lateral neck can reduce the invasiveness of the surgery and achieve better surgical visualization; moreover, this procedure decreases the risk of blood vessels and nerves injury(18). The operative technique was markedly different between pediatric surgeons and otolaryngologists. Ipsilateral tonsillectomy was performed in almost half of the operations performed by otolaryngologists, but in none of those performed at pediatric surgeon, Kajosaariet al. reported that it does not give any outcome benefits and should not be included into second branchial cleft fistula operation(14). Histologically, they are filled with a turbid yellow fluid containing cholesterol crystals and are lined by stratified squamous epithelium(6)

Post-operative complications include cranial nerves injury(3.5\%), damage to internal jugular vein, formation of persistent fistula, local infection, seroma, hematoma or scar formation(3.3\%) $(11,19)$. The overall recurrence rates following surgery were $3-4.9 \%$ in retrospective studies of 98 and 183 patients (3, 11). However, the recurrence rate may be as high as $22 \%$ if there is a history of infections or incomplete operation (20).

In conclusion, the best intervention for the treatment of second branchial anomaly is to excise the tract completely prior to an infection. It is wise to use a stent to delineate the fistula tract and reduce the risk of the recurrence.

\section{Conflict of interest}

No conflict of interest was declared by the authors.

\section{REFERENCES}

1. Lim LH, Hartnick CJ, Willging JP. A rare case of combined type I and II first branchial sinus. J Pediatr Surg 2003; 38: 12-3.

2. Turkyilmaz Z, Karabulut R, Bayazit YA, Sonmez K, Koybasioglu A, Yilmaz $M$, et al. Congenital neck masses in children and their embryologic and clinical features. B-ENT 2008;4:7-18.

3. Karabulut $R$, Sönmez K, Türkyilmaz Z, Ozen IO, Demiroğullari B, Güçlü $M M$, et al. Second branchial anomalies in children. ORL J Otorhinolaryngol Relat Spec 2005;67:160-2.

4. Ford GR, Balakrishnan A, Evans JN, Bailey CM. Branchial cleft and pouch anomalies. J Laryngol Otol 1992; 106: 137-43.

5. Yilmaz I, Cakmak O, Ozgirgin N, Boyvat F, Demirhan B. Complete fistula of the second banchial cleft: case report of catheter-aided total excision. Int J Pediatr Otorhinolaryngol 2004; 68: 1109-13.

6. Adams A, Mankad K, Offiah C, Childs L. Branchial cleft anomalies: a pictorial review of embryological development and spectrum of imaging findings. Insights Imaging 2016;7:69-76.

7. Bailey H. Branchial Cysts and Other Essays on Surgical Subjects in the Facio-Cervical Region,1st ed, Lewis, London, 1929.

8. Spinelli C, Rossi L, Strambi S, Piscioneri J, Natale G, Bertocchini A, et al. Branchial cleft and pouch anomalies in childhood: a report of 50 surgical cases. J Endocrinol Invest 2016;39:529-35.

9. Proctor B. Lateral vestigial cysts and fistulas of the neck. Laryngoscope 1955; 65:355-61.

10. Bajaj Y, Ifeacho S, Tweedie D, Jephson CG, Albert DM, Cochrane LA, et al. Branchial anomalies in children. Int J Pediatr Otorhinolaryngol 2011;75:1020-3.

11. Agaton-Bonilla FC, Gay-Escoda C. Diagnosis and treatment of branchial cleft cysts and fistulae. A retrospective study of 183 patients. Int J Oral Maxillofac Surg 1996;25:449-52.

12. Schroeder JW Jr, Mohyuddin N, Maddalozzo J. Branchial anomalies in the pediatric population. Otolaryngol Head Neck Surg 2007;137:28995.

13. Nour YA, Hassan MH, Gaafar A, Eldaly A. Deep neck infections of congenital causes. Otolaryngol Head Neck Surg 2011;144:365-71.

14. Kajosaari L, Mäkitie A, Salminen P, Klockars T. Second branchial cleft fistulae: patient characteristics and surgical outcome. Int J Pediatr Otorhinolaryngol 2014;78:1503-7.

15. Telander RL, Filston HC. Review of head and neck lesions in infancy and childhood. Surg Clin North Am 1992;72:1429-47.

16. Benson MT, Dalen K, Mancuso AA, Kerr HH, Cacciarelli AA, Mafee MF. Congenital anomalies of the branchial apparatus: embryology and pathologic anatomy. Radiographics 1992;12: 943-60.

17. Waldhausen JH. Branchial cleft and arch anomalies in children. Semin Pediatr Surg 2006; 15:64-9.

18. Chen J, Chen W, Zhang J, He F, Zhu Z, Tang S, et al. Endoscope-assisted second branchial cleft cyst resection via an incision along skin line on lateral neck. Eur Arch Otorhinolaryngol 2014;271:2789-93

19. Zaifullah S, Yunus MR, See GB. Diagnosis and treatment of branchial cleft anomalies in UKMMC: a 10-year retrospective study. Eur Arch Otorhinolaryngol 2013;270:1501-6

20. Choi SS, Zalzal GH. Branchial anomalies: a review of 52 cases. Laryngoscope 1995;105:909-13. 